Revista da Sociedade Brasileira de Medicina Tropical 27(2):115, abr-jun, 1994.

\title{
NECROLÓGIO
}

\section{VINCENT B. WIGGLESWORTH, FRS (1899-1994)}

This man founded insect physiology. There are several types of entomologists, taxomists following the linneal system, Behaviorists like Jean Henri Fabre, and now thanks to Wigglesworth ${ }^{1}$ insect physiologists. His master work is cited at the end of this brief homage. He made so many things clear about how insects function using especially Rhodnius prolixus which was sent by Brumpt to the London School of Tropical Medicine and Hygiene. Later he moved to Cambridge where he became Quick professor of biology. In that role he sponsored 3 groups of students from Gonville and Caius College who visited Brasilia to work in field projects of the
Nucleo Tropical of the University. Of the first group two of these former students are now acadernic professors. Wigglesworth showed clearly that among insects exist forms of intelligence difficult for the human mind to understand. Food for thought since insects will survive on this planet long after primates are history.

\section{REFERENCE}

1. Wigglesworth VB. The principles of insect physiology. $7^{\text {th }}$ edition, Chapman and Hall. London, 1992.

Philip Davis Marsden 